Original Paper

http://indexmedicus.afro.who.int

\title{
Impact of tillage and fertility management options on selected soil physical properties and sorghum yield
}

\author{
Idriss SERME ${ }^{1,2 *}$, Korodjouma OUATTARA ${ }^{1}$, Vincent LOGAH ${ }^{2}$, \\ Jean Baptisse TAONDA ${ }^{1}$, Saibou PALE $^{1}$, Charles QUANSAH ${ }^{2}$ \\ and C. Robert ABAIDOO ${ }^{2,3}$ \\ ${ }^{1}$ Institut de L'Environnement et de Recherches Agricoles (INERA), Burkina Faso. \\ ${ }^{2}$ Dept of Crop and Soil Sciences, Faculty of Agric. Kwame Nkrumah University of Science and Technology \\ (KNUST), Ghana. \\ ${ }^{3}$ IITA PMB 5320, Ibadan, Nigeria. \\ *Corresponding author, E-mail: sermeidriss@yahoo.fr; BP 476 Ouagadougou, Tel: 0022670232198
}

\begin{abstract}
Water and soil fertility are the most limiting biophysical factors affecting crop production in semi-arid West Africa. . This study was conducted in Nadion (south Sudan zone of Burkina Faso) to assess the impact of tillage practices (no-till, tied ridging; ripping and conventional tillage) combined with soil fertility management options (compost, NPK + Urea, crop residues, Compost+ NPK + Urea and a control) on soil moisture content and sorghum yield. The soil moisture was monitored weekly using the Time Domain Reflectometer (TDR) method and the soil bulk density was evaluated 30 days after planting. Zero tillage increased the soil water storage capacity compared to the other tillage practices at 0-30 $\mathrm{cm}$ depth. Sorghum straw residues application improved soil water content by $20 \%$. Conventional tillage decreased surface soil $(0-10 \mathrm{~cm})$ bulk density. Compost + NPK + Urea application increased sorghum yield by $74 \%$ over the control while, NPK + urea and compost increased sorghum grain yield by $50 \%$ and $29 \%$, respectively relative to the control (no soil amendment). Conventional tillage led to decrease in yield compared to zero tillage after two years of experimentation. The zero tillage combined with compost, NPK and urea increased sorghum yield by $28 \%$ compared to tied-ridging regardless of the fertility management options. Zero tillage is a promising option for sorghum production in the South Sudan agro-ecological zone of Burkina Faso.
\end{abstract}

(C) 2015 International Formulae Group. All rights reserved.

Keywords: Bulk density, fertility management, sorghum yield, South Sudan zone, tillage, water conservation.

\section{INTRODUCTION}

Sub-Saharan Africa (SSA) is the region where per capita food production is either on the decline, or nearly constant at a level that is less than adequate (FAO, 2007). During the last 15 years at the sub- regional level, only Western Africa has succeeded in increasing per capita food production significantly (FAO,
2011). The importance of agricultural development for poverty reduction and livelihood improvement in sub-Saharan Africa has been widely acknowledged and accepted (Bationo et al., 2012). However, limits aggravate the potential of agriculture for livelihood improvement. The agriculture in Sub-Saharan Africa is facing major 
challenges; among these are: (the ongoing population growth and the need for sufficient food, declining crop yields, severe soil degradation and climate change and rising uncertainties about future rainfall distribution (Battisti and Naylor, 2009).

During the last 30 years, several water management technologies such as tillage, stone rows, hedgerows, earth bunds, dikes, half-moon and Zai have been tested to improve soil water infiltration and storage (Zougmoré et al., 2004). Zougmoré et al. (2004) demonstrated that to soil productivity in the sub-Saharan zone is a function of improvement in water infiltration and storage in soil. In spite of this, water harvesting technologies have had limited impact on water productivity particularly, when such water harvesting technology is not combined with appropriate soil fertility management practices (Zougmoré et al., 2004). Although, the soils of this zone are of low inherent fertility (Bationo et al., 2012), analysis of water balance indicates a great potential for improved crop and water productivity in the region (Rockström, 2003). Yields gap analysis in several studies has shown water-related challenges in rain-fed agriculture of waterscarce tropics to be due to high-intensity rainfall with large spatial and temporal variability, rather than too low cumulative volumes of rainfall (Rockström et al., 2003).

In the sub-saharan regions, there is a need to develop adapted technologies for soil fertility and water management that optimize the efficient use of the limited water and soil resources to achieve sustainable agricultural production (Zougmoré et al., 2004). Several studies have shown that soils in this region are structurally degraded (Mando et al., 2005) and nutrient depleted (Kiba, 2012; Patel et al. 2013). However, there was a kind of subregional division in addressing soil and water management strategies to cope with land degradation in Sub-Saharan Africa. Indeed researches were more focused on conservation agriculture and cover cropping in the humidSavanna while rain water harvesting technologies were developed in the Sahel
(Vanlauwe et al., 2002; Kihara et al., 2012). This was partly due to the fact that no success has been achieved with zero tillage in the arid zones due to the hard-setting nature of the soil surface coupled with a keen competition for crop residues to be used for mulching (Mason et al., 2014) and for the farmers "no-till means no harvest". In addition, a general thought exists that there is no need to develop rain water harvesting technologies for areas in Africa with an annual mean rainfall more than $900 \mathrm{~mm}$. As a result of the general increasing trend of land degradation in Africa in the era of climate change, there is a need to develop and disseminate sustainable soil management options for sustainable crop production. Soil and water conservation technologies may contribute to achieve this goal in the SubSudan zone of Burkina Faso with annual rainfall greater than $900 \mathrm{~mm}$.

The objective of this study was to propose suitable combinations of soil and water conservation techniques and fertility management options for sorghum production in the South Sudan Zone of Burkina Faso. We examined and compared several options of water and nutrient management strategies as well as the potential for conservation agriculture in the zone.

\section{MATERIALS AND METHODS}

\section{Experimental site}

The experiment was conducted at Nadion ( $\mathrm{N} 11^{\circ} 7^{\prime} 60^{\prime \prime}$ and E $\left.2^{\circ} 13^{\prime} 0^{\prime \prime}\right)$, located at about $175 \mathrm{~km}$ south of Ouagadougou. Nadion is in the south Sudan zone of Burkina Faso with mean annual rainfall of $900 \mathrm{~mm}$ (Figure 1) and an average temperature of $35^{\circ} \mathrm{C}$. The soil order in the area is Lixisol (FAOUNESCO) and Sandy loam according to USDA with $66.4 \%$ sand, $26.9 \%$ silt and $6.8 \%$ clay. Physical and chemical properties of the soil of the study site are presented in Table 1 .

\section{Experimental design}

The experiment was laid out in a splitplot arranged in a randomized complete block design with three replications. The main plots were water conservation practices with four 
treatments namely; : No-till (direct planting); Minimum till (ripping); Tied ridging; the ridges were tied one month after sowing; Conventional tillage (ploughing using animal traction with soil inversion to $15 \mathrm{~cm}$ depth).

The sub -plots comprised soil amendment practices with five treatments which are : Control (no fertilizer, no compost and no crop residues); 2.5 tons per ha of compost every year; (37-23-14) kg/ha applied in the form $100 \mathrm{~kg}$ of NPK/ha (14-23-14) and $50 \mathrm{~kg}$ of Urea ha ${ }^{-1}(46 \% \mathrm{~N}) ; 100 \%$ crop residues retained (for the first year 2 tons $\mathrm{ha}^{-1}$ of crop residues (CR) was applied- meaning this treatment had no fertilizer, just residue); 2.5 tons per ha of compost $+100 \mathrm{~kg}$ of NPK $\mathrm{ha}^{-1}(14-23-14)$ and $50 \mathrm{~kg}$ of Urea $\mathrm{ha}^{-1}$ $(46 \% \mathrm{~N})$. Table 2 shows the mineral composition of the compost and the straw material used for mulching.

\section{Experimental setup}

Before the establishment of the experiment, $60 \mathrm{~cm}$ deep access tubes were placed in each sub-plot. Improved sorghum (Sorghum bicolor L. Moench) variety SARIASO 14 was sown on all the plots at a rate of 62750 seedlings per ha during the cropping seasons. Compost was applied before tilling and sowing. Mineral fertilizers were applied in splits: at 14 and 45 days after planting. Animal power was used for tillage operations. For no-till plots, compost was spread on the soil surface by hand. For the mulching, the crop residues were chopped into approximately $30 \mathrm{~cm}$ pieces and spread after tilling. Weeding was carried out twice during the entire growing stage.

\section{Data collection}

\section{Soil water content measurement}

Soil moisture was measured using the time domain reflectometry method (TDRTIME_FM) at depths of 0-20, 20-40, and 40$60 \mathrm{~cm}$. Three readings were made per depth every 7 days from sowing to harvesting (The moisture stock was evaluated weekly for a period of twelve weeks under the various tillage practices at $0-30 \mathrm{~cm}, 30-50 \mathrm{~cm}$ and $0-50 \mathrm{~cm}$ depths.

\section{Bulk density measurement}

The bulk density was determined 45 days after planting at $10 \mathrm{~cm}$ depth using the core method. A $400 \mathrm{~cm}^{3}$ cylinder was used in taking the core samples. These were oven dried at $105{ }^{\circ} \mathrm{C}$ to constant weight for 48 hours and weighed. The bulk density $\left(\rho_{\mathrm{b}}\right)$ was calculated as:

$$
\rho b=\frac{M s}{V t}
$$

where:

$$
\begin{aligned}
& \mathrm{Ms}=\text { Oven dry weight of soil }(\mathrm{g}) \\
& \mathrm{Vt}=\text { total volume of cylinder }\left(\mathrm{cm}^{3}\right)
\end{aligned}
$$

\section{Soil porosity}

Soil porosity (f) was calculated according to the equation:

$$
\% f=\left(1-\frac{\rho b}{\rho s}\right) \times 100
$$

where:

$$
\rho b=\text { soil bulk density }
$$

$\rho s=$ particle density; for the mineral Ferric Lixisol, a value of $2.6 \mathrm{Mg} \mathrm{m}^{-3}$ was used.

\section{Aeration porosity}

Aeration porosity (fa) was calculated as:

$f a=f-\theta$

where:

$$
\begin{aligned}
& \mathrm{f}=\text { porosity } \\
& \theta \mathrm{v}=\text { volumetric water content }
\end{aligned}
$$

\section{Harvesting}

Sorghum was harvested after four months and yield components expressed in $\mathrm{kg}$ $\mathrm{ha}^{-1}$ after drying to constant weight.

\section{Statistical analyses}

Mixed models analysis was conducted using pro Genstat package (version 9.2) for the sorghum growth and yield data and for the repeated measurement data. The standard error of the difference of means (Sed) was used to separate significant treatment means at $5 \%$ probability.

Soil moisture content was subjected to analysis of variance (ANOVA) and the 
treatment means separated using the least significant difference (LSD) method at $5 \%$.

\section{RESULTS}

Effect of tillage practices on soil bulk density and porosity

The mixed model analysis (Tables 3 and 4) showed tillage to significantly $(\mathrm{P}<0.05)$ affect bulk density and porosity. Soil amendments and their interaction, however, did not significantly influence the latter parameter. The mean values of bulk density and porosity at $0-10 \mathrm{~cm}$ depth under the tillage systems (Table 3) ranged from 1.58 to $1.66 \mathrm{Mg} \mathrm{m}^{-3}$ with a decreasing trend of zero > ripping > tied-ridging > conventional tillage. Apart from the significant differences in the bulk density of the former two tillage practices and that of the conventional tillage, all other differences were not significant. Conventional tillage recorded the lowest bulk density.

As bulk density increased, total and aeration porosities decreased. Total porosity (Table 3), ranging from 36.04 to $39.00 \%$, followed the converse trend of the bulk density. The conventional tillage had the highest total porosity and the zero tillage recorded the lowest. The total porosity under zero tillage and ripping practices were not significantly different. The fertility management options did not significantly affect the bulk density, the total porosity and the aeration porosity (Table 4 ).

\section{Effect of tillage and mulching on soil water stock}

The response of soil moisture stock to tillage varied with time and soil depth (Figures $2-4$ ). At the $0-30 \mathrm{~cm}$ depth (Figure 2 ), soil water stock was different under the tillage practices with higher values under zero tillage than the other tillage practices from the third to the ninth week except in the $4^{\text {th }}$ week when ripping and tied-ridging recorded higher values of 117 and $132 \mathrm{~mm}$ respectively. The mean weekly soil moisture over the 12 week period, ranged from 44.15 to $53.66 \mathrm{~mm}$ under Ripping and Zero tillage respectively. At the
$30-50 \mathrm{~cm}$ depth (Figure 3), soil water stock was significantly different only at the $4^{\text {th }}$ and $5^{\text {th }}$ weeks (peak rainfall period) with the highest and lowest values observed under tied ridging and conventional tillage, respectively. The mean weekly water stock over the 12 weeks period followed a trend of tied ridging $>$ conventional tillage $>$ zero tillage $>$ ripping with values ranging between 31.78 and 43.72 $\mathrm{mm}$ respectively. Cumulative soil moisture stock at $0-50 \mathrm{~cm}$ (Figure 4) also varied significantly only at the $4^{\text {th }}$ and $5^{\text {th }}$ weeks with tied ridging recording the highest value. The mean weekly soil moisture stock ranked as tied-ridging > zero tillage > conventional tillage $>$ ripping. With the lowest $(73.84 \mathrm{~mm})$ recorded under ripping and the highest (86.04 $\mathrm{mm}$ ) under tied - ridging.

The weekly soil moisture stock varied significantly only at the $4^{\text {th }}$ and $5^{\text {th }}$ weeks at 0 - $50 \mathrm{~cm}$ depth under no much and mulch practices (Figure 5). The same trend prevailed over the remaining weeks, except that the differences were not significant. The mean weekly soil water stock over the 12 week period ranged from 74.46 to $79.84 \mathrm{~mm}$ under no much and mulch respectively at $0-50 \mathrm{~cm}$ depth.

Tillage and fertility management options effect on sorghum yield

The mixed model analysis did not show any significant difference between the tillage practices at chi probability level of $5 \%$ (Tables 5 and 6). But in 2012, conventional tillage and the tied-ridging increased sorghum grain yield respectively by $29 \%$ and $40 \%$ compared to the no - till practice (Table 5). The mixed models analysis at chi probability level of 5\% showed significant differences between fertility management options with respect to sorghum yields (Tables 5 - 6). In 2012, Compost + NPK + urea, NPK + urea and compost application increased grain yield respectively by $102 \%, 69 \%$ and $36 \%$ over the control (Table 5). In 2013, application of compost + NPK + urea, NPK + urea and compost led to $74 \%, 50 \%$ and $29 \%$ increase respectively in grain yield. In the same year, 
grain yield decrease of $30 \%$ was observed under mulching compared to the control (Table 6). Mulching did not influence grain yield ( $p>0.05)$ in 2013. During the first year of the experiment, the interaction of tillage practices and fertility management options did not impact significantly on sorghum grain (Table 5). In 2013 however, the interaction between tillage practices and fertility management options significantly influenced sorghum grain yield (Table 6). The two - year cumulative effect of zero tillage $\mathrm{x}$ compost + NPK + urea increased sorghum grain yield by $28 \%$ compared to the conventional tillage with the same fertility management options (Figure $6)$.

Table 1: Physico-chemical characteristics of the soil at the research site.

\begin{tabular}{|c|c|c|}
\hline Soil depth $(\mathrm{cm})$ & 0-10 & $10-20$ \\
\hline Organic carbon $\left.\left(\mathrm{g} \mathrm{kg}^{-1}\right)\right)$ & 10.6 & 8.9 \\
\hline $\mathrm{P}_{\mathrm{H} 2 \mathrm{O}}^{\mathrm{H}}(1: 2.5)$ & 6.00 & 5.70 \\
\hline Total nitrogen $\left.\left(\mathrm{g} \mathrm{kg}^{-1}\right)\right)$ & 00.6 & 00.4 \\
\hline Total phosphorus $\left(\mathrm{mg} \mathrm{kg}^{-1}\right)$ & 312.17 & 246.67 \\
\hline \multicolumn{3}{|l|}{ Exchangleable bases $\left.\left(\mathrm{cmol}^{+}\right) \mathrm{kg}^{-1}\right)$} \\
\hline Calcium & 4.59 & 3.03 \\
\hline Magnesium & 0.96 & 0.75 \\
\hline Potassium & 0.15 & 0.13 \\
\hline Sodium & 0.10 & 0.09 \\
\hline Cation Exchange Capacity $\left.\left(\mathrm{cmol}^{+}\right) \mathrm{kg}^{-1}\right)$ & 6.24 & 7.60 \\
\hline Bulk density $\left(\mathrm{gcm}^{-3}\right)$ & 1.64 & 1.62 \\
\hline Sand $(\%)$ & 66.30 & 65.00 \\
\hline Silt (\%) & 26.90 & 26.10 \\
\hline Clay $(\%)$ & 6.80 & 8.90 \\
\hline
\end{tabular}

Table 2: Compost and sorghum straw chemical characteristics.

\begin{tabular}{lllcll}
\hline Organic materials & Organic C $(\%)$ & Total N $(\%)$ & $\mathbf{C / N}$ & $\begin{array}{c}\text { Total P } \\
\left(\mathbf{g ~ k g}^{-\mathbf{1}}\right)\end{array}$ & $\begin{array}{l}\text { Total K } \\
\left(\mathbf{g ~ k g}^{-\mathbf{1}}\right)\end{array}$ \\
\hline Compost & 19.05 & 1.01 & 18.82 & 2.85 & 12.1 \\
Straw & 53.83 & 0.39 & 135.41 & 2.92 & 15.9 \\
\hline
\end{tabular}

Table 2: Effect of tillage practices on soil bulk density, porosity and aeration porosity at $0-10 \mathrm{~cm}$ depth.

\begin{tabular}{lccc}
\hline Tillage practices & Bulk density $\left(\mathbf{M g m}^{-\mathbf{3}}\right)$ & Porosity $(\boldsymbol{\%})$ & $\begin{array}{c}\text { Aeration porosity } \\
(\boldsymbol{\%})\end{array}$ \\
\hline Zero tillage & 1.66 & 36.04 & 27.14 \\
Ripping & 1.65 & 36.42 & 29.51 \\
Tied - ridging & 1.62 & 37.53 & 27.93 \\
Conventional tillage & 1.58 & 39.00 & 31.09 \\
Chi $^{2}$ probability & 0.016 & 0.02 & 0.03 \\
SED & 0.05 & 1.02 & 1.46 \\
\hline
\end{tabular}


I. SERME et al. / Int. J. Biol. Chem. Sci. 9(3): 1154-1170, 2015

Table 3: Effect of fertility management options on soil bulk density, porosity and aeration porosity at $0-10 \mathrm{~cm}$ depth.

\begin{tabular}{lccc}
\hline Fertility management & Bulk Density $\left(\mathbf{M g ~ m}^{-3}\right)$ & $\begin{array}{c}\text { Porosity } \\
(\boldsymbol{\%})\end{array}$ & $\begin{array}{c}\text { Aeration porosity } \\
(\boldsymbol{\%})\end{array}$ \\
\hline Control & 1.62 & 37.59 & 29.44 \\
Compost & 1.62 & 37.64 & 30.44 \\
NPK + Urea & 1.64 & 36.59 & 29.40 \\
Compost + NPK + Urea & 1.64 & 36.81 & 28.80 \\
Mulch & 1.62 & 37.62 & 28.51 \\
\hline Chi ${ }^{2}$ probability & 0.81 & 0.81 & 0.23 \\
SED & 0.03 & 1.14 & 1.63 \\
\hline
\end{tabular}

Table 5: Mixed model analysis of sorghun grain yield in 2012.

\begin{tabular}{|c|c|c|c|c|c|}
\hline Fixed term & Wald statistic & & & $\mathrm{Chi}^{2} \mathrm{pr}$ & \\
\hline Tillage_practice & 0,74 & & & 0,863 & \\
\hline Fertility_managenent & 29,58 & & & $<0.001$ & \\
\hline Tillage_practice*fertility_managenent & 12,64 & & & 0,396 & \\
\hline Fertility_managenent & Grain Yield(kg/ha) & Increase $(\%)$ & Tillage practices & Grain Yield(kg/ha) & Increase $(\%)$ \\
\hline Control & 862 & & Zero tillage & 966 & \\
\hline Compost & 1176 & 36 & Ripping & 1105 & 14 \\
\hline NPK+Urea & 1454 & 69 & Tied ridging & 1353 & 40 \\
\hline Mulching & 602 & -30 & Conventional Tillage & 1243 & 29 \\
\hline Compost + NPK + Urea & 1740 & 102 & & & \\
\hline Sed & 236 & & Sed & 478 & \\
\hline
\end{tabular}


I. SERME et al. / Int. J. Biol. Chem. Sci. 9(3): 1154-1170, 2015

Table 6: Mixed model analysis for sorghum grain yield in 2013.

\begin{tabular}{|c|c|c|c|c|c|}
\hline Fixed term & Wald statistic & & & $\mathrm{Chi}^{2} \mathrm{pr}$ & \\
\hline Tillage_practice & 2.33 & & & 0.507 & \\
\hline Fertility_managenent & 156.97 & & & $<0.001$ & \\
\hline Tillage_practice*fertility_managenent & 32.02 & & & 0.001 & \\
\hline Grain_yield2012 & 47.48 & & & $<0.001$ & \\
\hline Fertility_managenent & $\begin{array}{c}\text { Grain } \\
\text { Yield(kg/ha) }\end{array}$ & $\begin{array}{c}\text { Increase } \\
(\%)\end{array}$ & $\begin{array}{l}\text { Tillage } \\
\text { practices }\end{array}$ & $\begin{array}{c}\text { Grain } \\
\text { Yield(kg/ha) }\end{array}$ & $\begin{array}{c}\text { Increase } \\
(\%)\end{array}$ \\
\hline Control & 1545 & & Zero tillage & 2116 & \\
\hline Compost & 1989 & 29 & Ripping & 1850 & -13 \\
\hline NPK+Urea & 2320 & 50 & Tied ridging & 2014 & -5 \\
\hline Mulching & 1543 & 0 & $\begin{array}{c}\text { Conventional } \\
\text { tillage }\end{array}$ & 2087 & -1 \\
\hline Compost + NPK + Urea & 2687 & 74 & & & \\
\hline Sed & 250 & & Sed & 299 & \\
\hline
\end{tabular}


I. SERME et al. / Int. J. Biol. Chem. Sci. 9(3): 1154-1170, 2015

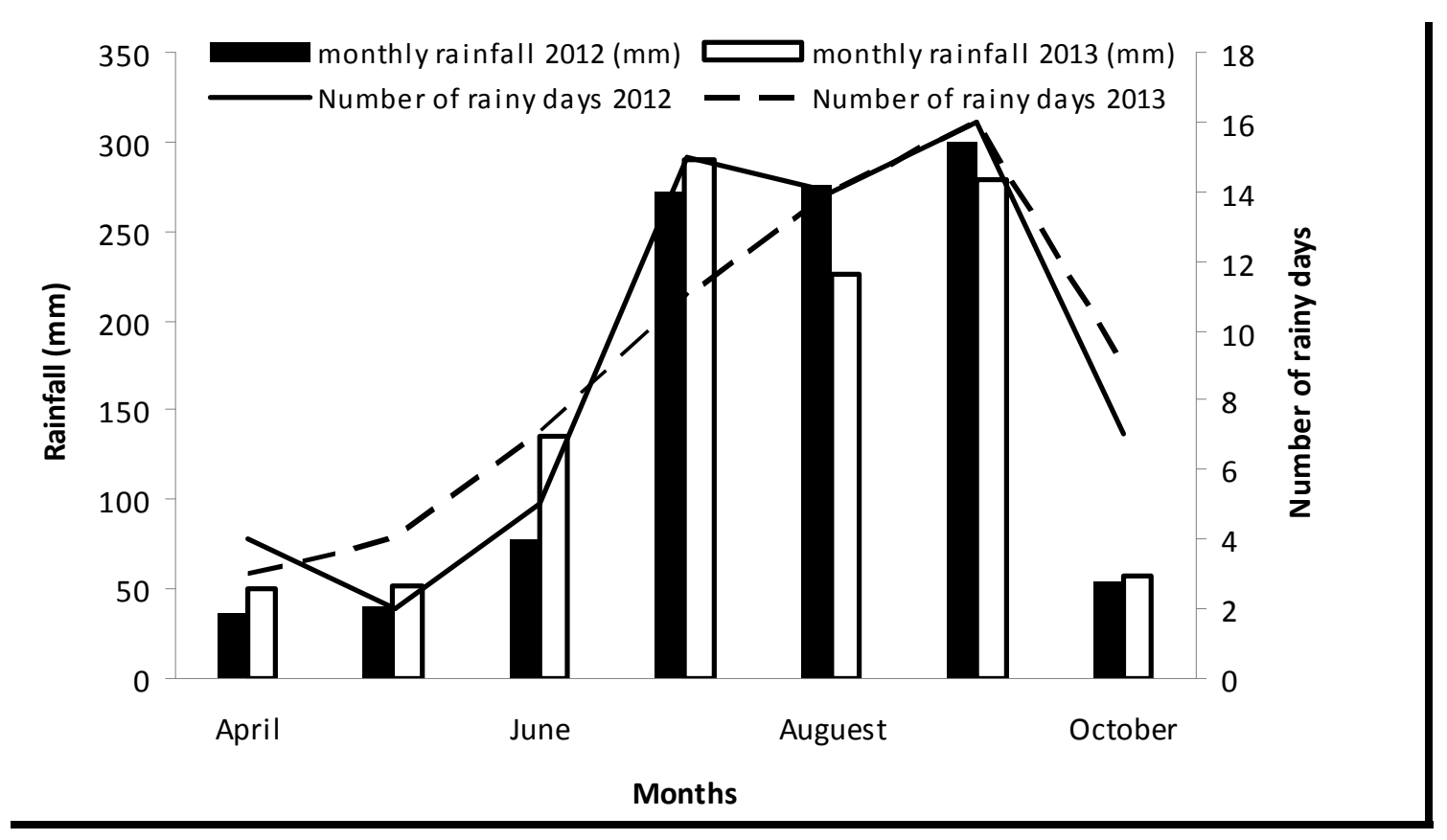

Figure 1: Rainfall distribution in Nadion in 2012 and 2013. 
I. SERME et al. / Int. J. Biol. Chem. Sci. 9(3): 1154-1170, 2015

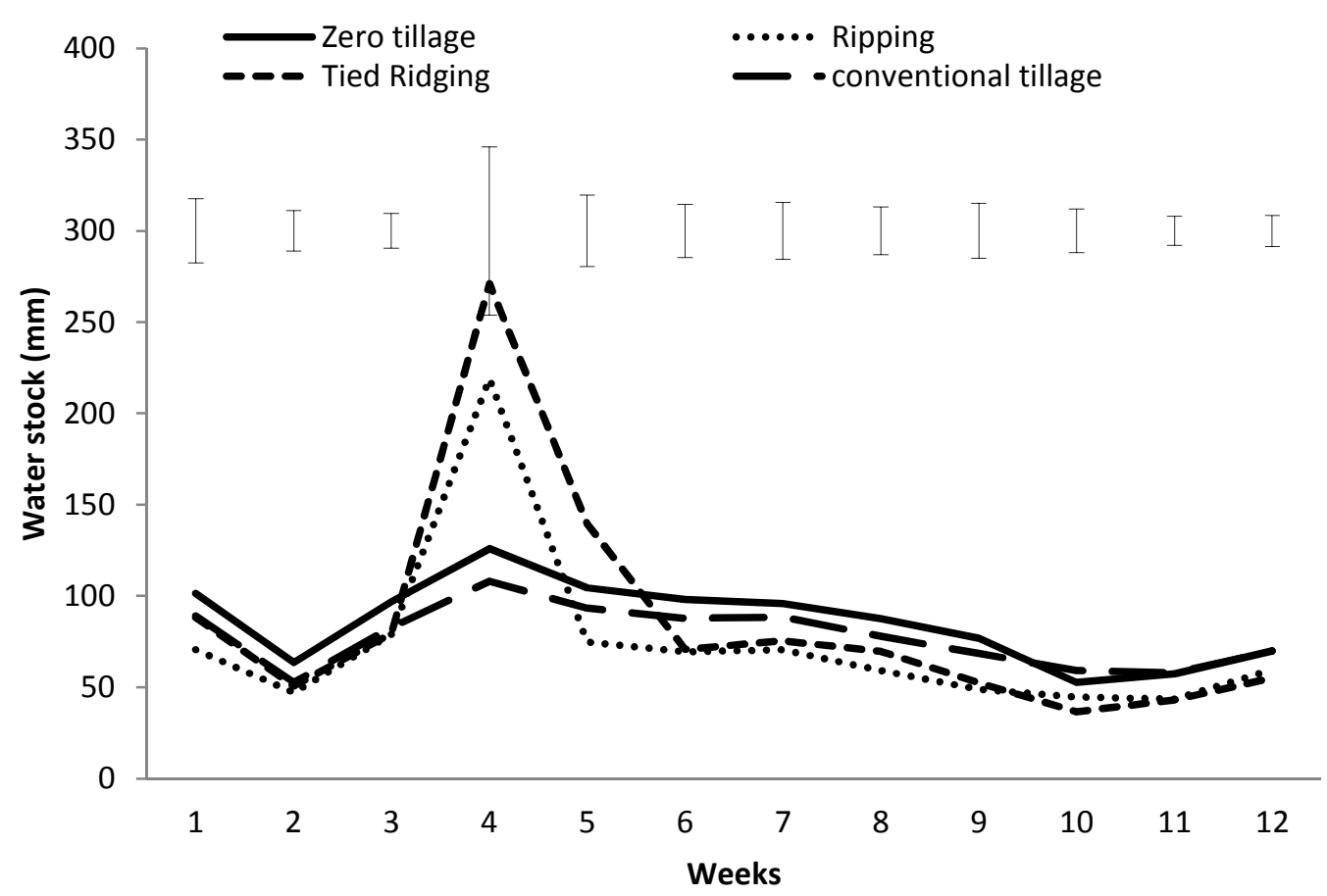

Figure 2: Soil water stock as affected by tillage practices at $0-30 \mathrm{~cm}$ depth. Error bars are the LSD at P=0.05. 


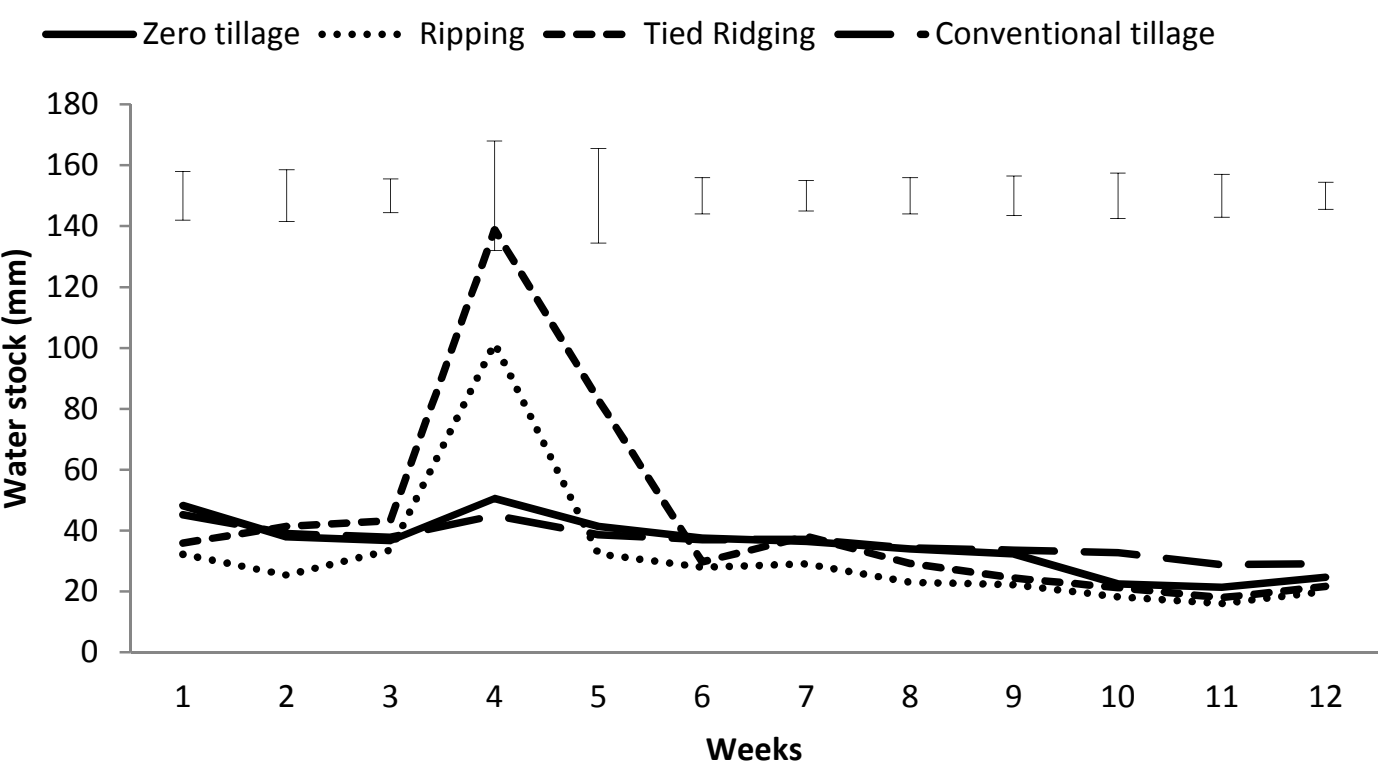

Figure 3: Soil water stock as affected by tillage practices at $30-50 \mathrm{~cm}$ depth. Error bars are the LSD at $\mathrm{P}=0.05$. 
I. SERME et al. / Int. J. Biol. Chem. Sci. 9(3): 1154-1170, 2015

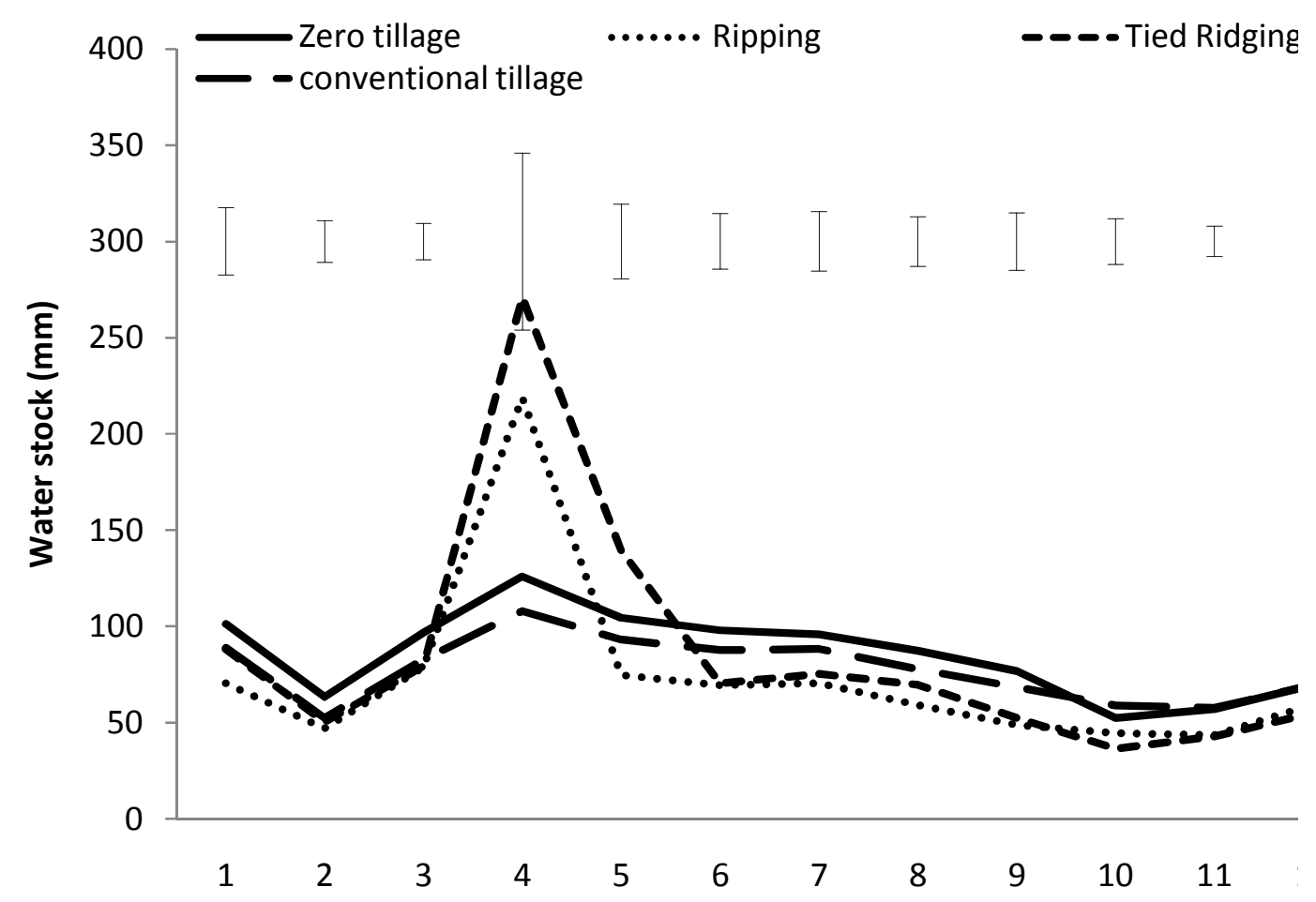

Figure 4: Soil water stock as affected by tillage practices at $0-50 \mathrm{~cm}$ depth. Error bars are the LSD at P=0.05. 
I. SERME et al. / Int. J. Biol. Chem. Sci. 9(3): 1154-1170, 2015

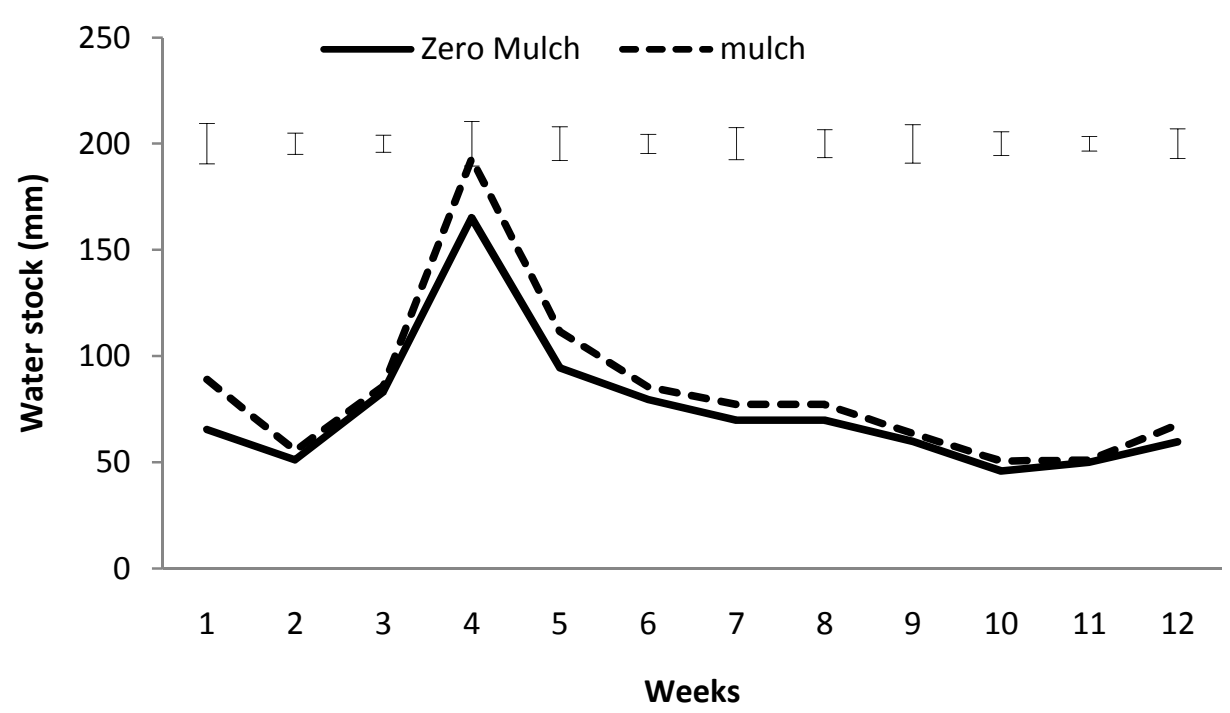

Figure 5: Soil water stock as affected by mulching at $0-50 \mathrm{~cm}$ depth. Error bars are the LSD at $\mathrm{P}=0.05$. 


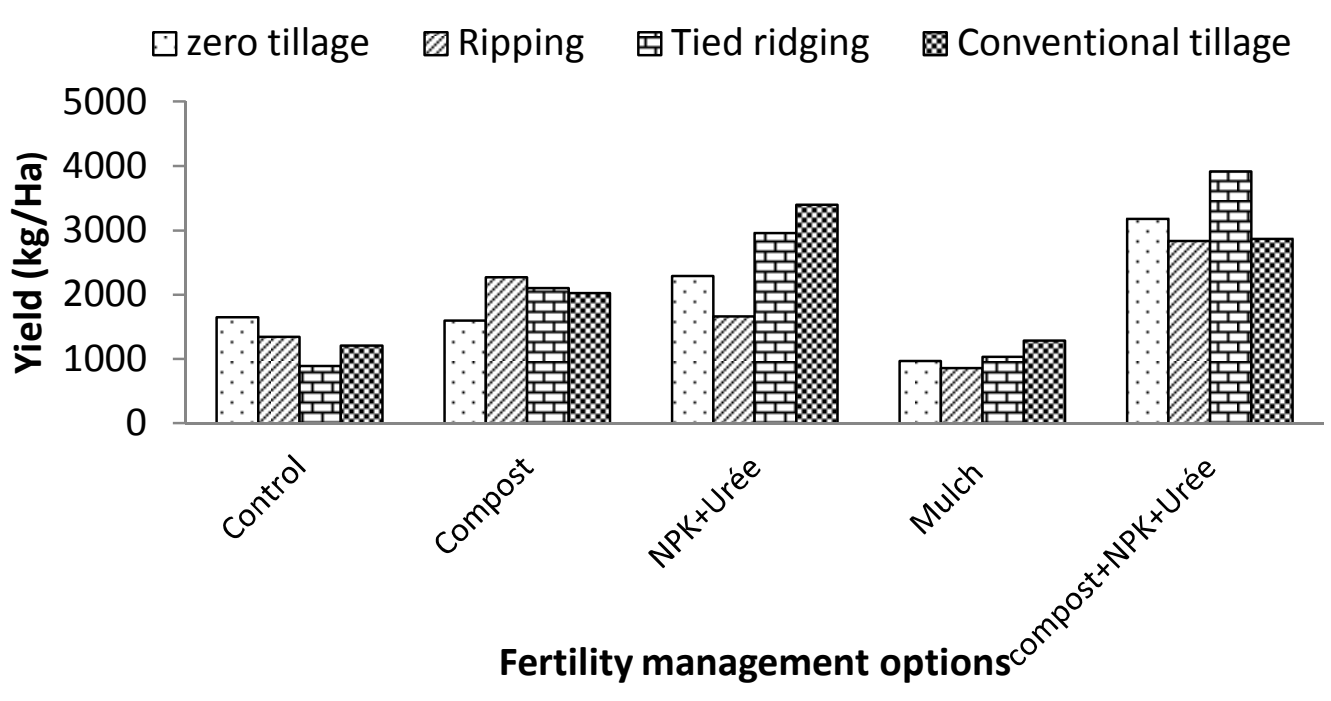

Figure 6: Interaction between tillage practices and fertility management options on sorghum grain yield in 2013. 


\section{DISCUSSION}

Effect of tillage practices on soil bulk density, total porosity and aeration porosity

The bulk density at $0-10 \mathrm{~cm}$ depth, measured 45 days after the imposition of the tillage treatments were generally high especially under zero tillage. The figure falls within the bulk density of sandy loams with a risk for root restriction (Zida, 2011). Under such circumstances, some form of tillage is required to loosen the soil to provide a favourable bio-physical condition for seedling emergence, crop growth and yield. Thus, all tillage beyond zero, recorded lower bulk densities but more significantly under conventional tillage, followed by tied-ridging. Similar observations of higher bulk densities under zero tillage than conventional tillage have been reported (Xu and Mermoud, 2001; Dam et al., 2005; Zida, 2011). Ouattara (2007) further observed that soils tend to have the lowest bulk density and highest total porosity immediately after ploughing.

By pulverizing the soil with changes in soil structure, the loosening of the top $10 \mathrm{~cm}$ of the soil by tillage, particularly the conventional and tied - ridging reduced the mass of soil per unit volume with a consequent reduction in bulk density. Correspondingly, total and aeration porosities increased under these tillage practices than the zero tillage. The 5\% lower bulk density observed under the conventional than zero tillage thus resulted in an increase in $8 \%$ and $15 \%$ in total porosity and aeration porosity, respectively. The aeration porosity is therefore more sensitive to soil compaction than the total porosity. These impacts need to be considered in the use of bulk density, total and aeration porosities as soil quality indicators affecting soil structure under various tillage practices and their implications for soil functions and processes (Hou et al., 2012). Lessons drawn from these earlier studies may inform the development of appropriate suitable land management strategies for the future cultivation of the soils in the experimental area.

\section{Tillage practices and soil moisture}

The mean moisture storage at $0-50 \mathrm{~cm}$ depth, although not significant, followed a trend of tied-ridging $>$ zero $>$ conventional > ripping. This may be due to the increase in spore, enhancing saturated hydraulic conductivity, which in turn, enhanced water flow into deeper depth for storage (Ouattara, 2007). At the $0-30 \mathrm{~cm}$ depth, the mean soil moisture stored was higher under zero tillage and tied-ridging than conventional tillage and ripping practices. At this depth, the highest soil moisture stored under zero tillage may be due to the role of crop residues in conserving moisture through reduced evaporation as observed by Zougmoré et al. (2004). Soil moisture at $30-50 \mathrm{~cm}$ depth was highest under tied-ridging whilst ripping recorded the least. The macrospores and the relatively higher saturated hydraulic conductivity of the tied ridging as observed by Ouattara (2007) presumably allowed more water flow into deeper layers with the furrows acting as better moisture conservation zones than those of ripping practice. These zones replenish depleted moisture in the ridges due to uptake by the roots in response to decreased water potential in the ridge.

At the peak rainfall period, the retention of rain water in the basins created by Tied-ridging and the water conservation slits under Ripping allowed more contact time for water infiltration into the soil than the zero and conventional tillage and this probably explains the variation in soil moisture storage at the peak of rainfall. The peak rainfall period ( $4^{\text {th }}$ week) was followed by rainless period of about two weeks and few rains thereafter. This period was more of soil moisture depletion presumably through transpiration and evapotranspiration. Assuming a constant rate of transpiration and insignificant deep drainage, soil moisture depletion would be mainly through evaporation. In this context, the zero and the conventional tillage were better practices in conserving stored moisture. The former by reducing the energy required for evaporation, temperature, the saturation deficit at the soil and residue interface and 
turbulent air movement at the soil surface. The latter through soil mulch produced by ploughing which breaks the continuity of the micropores in the subsoil to the surface thereby reducing moisture supply through capillary to the surface for evaporation. For the same reasons alluded to for moisture conservation under zero tillage, mulching also improved soil moisture at both depth and time of measurement more than no-mulching plots. Favourable effects of mulching on soil water retention have been reported for the surface layer (Unger et al., 2012). Zougmoré et al. (2004) reported $34-50 \%$ reduction in soil water evaporation as a result of crop residue mulching. On the sandy loam soils in the experimental area, emphasis must be placed on optimizing soil moisture storage during the peak periods of rainfall. Beyond this period, any incidence in reduced rainfall results in a drastic depletion of available soil moisture in the rooting zone for sustainable crop production.

\section{Impact of tillage and fertility management effect on sorghum yield}

Zero tillage and reduced tillage systems have been reported to perform better (Mrabet, 2002), similarly and sometimes poorer than conventional tillage systems in terms of yields (Ouattara, 2007). In this study, the fact that the statistical analysis did not show any significant difference between the tillage practices may be due to the high variability in the data because the tillage practices were located in the main plots. Rainfall was not a limiting factor during the two years. The relative increase in sorghum grain yield during the second year of the experiment can be explained by the cumulative effect of two consecutive no - till practices leading to improvements in soil structure and therefore rooting and soil water relations, or simply response to the rainfall regime. The beneficial effects of zero tillage and tied-ridging on sorghum yield varied with differences in amount and distribution of rainfall and fertility management options as observed. Decrease in yield under tied-ridging compare to no-till have also been reported in Kenya by Kihara et al. (2012) and was attributed to high rainfall. Studies have shown that the positive effect of zero tillage on crop yield is observed after some years (Ogle et al., 2012). Contrasting results were obtained by Zougmoré et al. (2004) in the Sahelian part of Burkina Faso where the annual rainfall is lower than 700 mm. Tesfahunegn (2012) reported $45 \%$ increase in sorghum grain yield under tied ridging practice compared to zero tillage in Abergelle area in northern Ethiopia.

Sorghum performance under different fertility management options could be related to $\mathrm{N}$ and $\mathrm{P}$ availability to crops, the compost quality and the nutrient release patterns by the compost. Higher yields obtained in compost + fertilizer treatments could be attributed to the nutrients being readily made available from the fertilizers and also the improvement of mineralization of the compost with the application of mineral fertilizer as observed by Zougmoré et al. (2008). In compost treatments, nutrients availability depends on nutrient concentration and release in synchrony with crop needs (Bationo et al., 2012).

As productivity of most soils in their native state in the study area is very low (Kiba, 2012), applying plant nutrients (compost, urea and NPK) to these poor soils induced great positive reaction to crop production, particularly during good rainfall years when soil moisture constraint is less (Zougmoré et al., 2004). In plots with compost application, the mineralization of compost released not only the macro nutrients such as nitrogen and phosphorus but also considerable amounts of micronutrients for plant use (Zougmoré et al., 2008). Significant sorghum response to chemical fertilizer application in this study indicated the importance of fertilizer in the cropping system. This was well demonstrated by Vanlauwe et al. (2011) who revealed greater agronomic performance when mineral fertilizer was combined with manure or compost. 


\section{Conclusion}

This study showed that soil bulk density and soil water content are affected by tillage practices. Sorghum yield varied with the soil fertility management options. The tied ridging can be used as water conservation practice in a South Sudan Zone of Burkina Faso. Mulch application only increases soil water storage but leads to a decrease in sorghum yield. Zero tillage is a promising option for sorghum production in the South Sudan agro-ecological zone of Burkina Faso.

\section{ACKNOWLEGMENTS}

The authors are grateful to Alliance for Green Revolution in Africa (AGRA) and the Mcknight foundation for funding this research work.

\section{REFERENCES}

Bationo A, Kimetu J, Kihara J, Traore Z, Bagayoko M, Bado V, Lompo F, Tabo R, Koala S. 2012. Cropping systems in the Sudano-Sahelian zone: Implications on soil fertility management over varied seasons. In Lessons Learned from LongTerm Soil Fertility Management Experiments in Africa. Springer: Netherlands; 137-158.

Battisti DS, Naylor RL. 2009. Historical warnings of future food insecurity with unprecedented seasonal heat. Science, 323(5911): 240-244.

Dam RF, Mehdi BB, Burgess MSE, Madramootoo CA, Mehuys GR, Callum IR. 2005. Soil bulk density and crop yield under eleven consecutive years of corn with different tillage and residue practices in a sandy loam soil in central Canada. Soil and Tillage Research, 84(1): 41-53.

FAO (Agriculture Organization of the United Nations). 2007. Land and Water development Division, Georeferenced Database on Africa Dams.

FAO (Agriculture Organization of the United Nations). 2011. FAOSTAT, 2011.

Hou XQ, Li R, Jia ZK, Han QF, Yang BP, Nie JF. 2012. Effects of rotational tillage practices on soil structure, organic carbon concentration and crop yields in semi-arid areas of northwest China. Soil Use and Management, 28(4): 551-558.

Kiba I. 2012. Diversité des modes de gestion de la fertilité des sols et leurs effets sur la qualité des sols et la production des cultures en zones urbaine, péri-urbaine et rurale au Burkina Faso. Thèse de doctorat unique. IDR/UPB. Burkina Faso, p. 142.

Kihara J, Martius C, Bationo A, Thuita M, Lesueur D, Herrmann L, Amelang W, Vlek PLG. 2012. Soil aggregation and total diversity of bacteria and fungi in various tillage systems of sub-humid and semi-arid Kenya. Applied Soil Ecology, 58: $12-20$.

Mando A, Ouattara B, Somado AE, Wopereis MCS, Stroosnijder L, Breman H. 2005. Longterm effects of fallow, tillage and manure application on soil organic matter and nitrogen fractions and on sorghum yield under Sudano Sahelian conditions. Soil Use and Management, 21(1): 25-31.

Mason SC, Ouattara K, Taonda SJB, Palé S, Sohoro A, Kaboré D. 2014. Soil and cropping system research in semi-arid West Africa as related to the potential for conservation agriculture. International Journal of Agricultural Sustainability, 2(4): 1-15.

Mrabet R. 2002. Wheat yield and water use efficiency under contrasting residue and tillage management systems in a semiarid area of Morocco. Exp. Agric., 38: 237248.

Ogle SM, Swan A, Paustian K. 2012. No-till management impacts on crop productivity, carbon input and soil carbon sequestration. Agriculture, Ecosystems \& Environment, 149: 37-49.

Ouattara K. 2007. Improved soil and water conservatory managements for cottonmaize rotation system in the western cotton area of Burkina Faso. PhD thesis, SLU, Umea, p.72.

Patel HH, Patel TU, Patel PS, Patel AJ, Desai GB. 2013. Response of Rabi sorghum 
[Sorghum bicolor (L.) Moench] to land configuration and nutrient management. BIOINFOLET-A Quarterly, Journal of Life Sciences, 10(2a): 387389.

Rockström J, Barron J, Fox P. 2003. Water productivity in rain-fed agriculture: challenges and opportunities for smallholder farmers in drought-prone tropical agroecosystems. Water Productivity in Agriculture: Limits and Opportunities for Improvement, 85(669): 1-8.

Tesfahunegn GB. 2012. Effect of Tillage and Fertilizer Practices on Sorghum Production in Abergelle Area, Northern Ethiopia. Momona Ethiopian Journal of Science, 4(2): 52-69.

Unger P, Baumhardt R, Arriga FJ. 2012. Mulch tillage for conserving soil water. Advances in Soil Science, 3: 427453.

Vanlauwe B, Kihara J, Chivenge P, Pypers P, Coe R, Six J. 2011. Agronomic use efficiency of $\mathrm{N}$ fertilizer in maize-based systems in sub-Saharan Africa within the context of integrated soil fertility management. Plant and Soil, 339(2): 3550 .
Vanlauwe B, Palm CA, Murwira HK, Merckx R. 2002. Organic resource management in sub-Saharan Africa: validation of a residue quality-driven decision support system. Agronomie, 22: 839- 846.

$\mathrm{Xu}$ D, Mermoud A. 2001. Topsoil properties as affected by tillage practices in North China. Soil and Tillage Research, 60(1): 11-19.

Zida Z. 2011. Long-term effects of conservation soil management in Saria, Burkina Faso, West Africa. PhD thesis. Wageningen University and Research Centre, p. 157.

Zougmoré R, Mando A, Stroosnijder L. 2004. Effect of soil and water conservation and nutrient management on the soil-plant water balance in semi-arid Burkina

Faso. Agricultural Water Management, 65(2): 103-120.

Zougmoré R, Mando A, Stroosnijder L. 2008. Benefits of integrated soil fertility and water management in semi-arid West Africa: an example study in Burkina Faso. Nutrient Cycling in Agroecosystem, 88(1): 17-27. 